\title{
DOI 10.26886/2520-7474.5(43)2020.9
}

\section{UDC: 378.091.3:377.011.3-051:004}

\section{ACTUALIZATION OF TRAINING OF FUTURE SPECIALISTS BY MEANS OF INFORMATION AND TELECOMMUNICATION SUPPORT IN EDUCATIONAL INSTITUTIONS}

\author{
V. Tymoshenko, postgraduate student \\ http://orcid.org/0000-0001-6379-0204 \\ e-mail: tymoshenko_vi@ukr.net \\ National Pedagogical Drahomanov University; Ukraine, Kyiv
}

The pedagogical research on the relevance of professional training of future specialists by means of information and telecommunication support in educational institutions with the help of general and special theoretical methods of analysis was carried out, but among them the method of content analysis was chosen as the predominant one. Methodologically substantiated information and telecommunication support for training of future specialists of educational institutions and specified the conceptual and categorical apparatus of the research problem, systematized information and telecommunication resource base, namely decision support systems, tools, tools, platforms and resources of information and telecommunication support for professional training educational institutions.

Key words: professional training, content analysis, information and telecommunication support, resources, platforms.

аспірант, Тимошенко В. І., Актуалізація підготовки майбутніх фрахівців засобами інформаційно-телекомунікаційного забезпечення у закладах освіти / Національний педагогічний університет імені М. П. Драгоманова, Україна, Київ

Здійснено педагогічне дослідження щодо актуальності профресійної підготовки майбутніх фрахівців засобами інформаційно- 
телекомунікаційного забезпечення у закладах освіти за допомогою загальних та спеціальних теоретичних методів аналізу, але серед них превалюючим було обрано метод конетент-аналізу. Методологічно обгрунтовано інформаційно-телекомунікаційне забезпечення підготовки майбутніх фрахівців закладів освіти та конкретизовано понятійно-категоріальний апарат проблеми дослідження, систематизовано інформаційно-телекомунікаційну ресурсну базу, а саме системи підтримки прийняття рішень, засоби, інструментарій, платформи та ресурси інформаційнотелекомунікаційного забезпечення профресійної підготовки майбутніх фрахівців в закладах освіти.

Ключові слова: професійна підготовка фрахівців, контент-аналіз, інформаційно-телекомунікаційне забезпечення, ресурси, платформи.

Вступ. В законодавстві України визначено першочергові пріоритети з питань реалізації Національної програми інформатизації, у тому числі створення нормативно-правової бази інформаційнотелекомунікаційного (далі - ITК) забезпечення включно за системою захисту авторських прав та персональних особистих даних, розроблення національних стандартів у галузі цифровізації економіки та освіти, науки та інноватики, формування ІТК-інфраструктури, мережево-платформної організації інституційної життєдіяльності насамперед з гармонізацією змішаних, мобільних і мережевих фрорм магістралей передачі сучасних наукових інформаційних даних, системної розбудови новітніх трансляційних каналів, волокно-оптичних і супутникових систем інтерактивного онлайн зв'язку, розбудови архітектоніки комп'ютерно-організованої телекомунікаційної мережі системи освіти, науки й інноватики та академічної культури як загальної компоненти світової мережі науково-метричних Інтернет-ресурсів, 
забезпечення заходів інформаційної безпеки соціокультурних, освітньо-наукових форм та систем, вебо-метричного та науковометричного потенціалу академічних шкіл закладів освіти (далі - 30), в тому числі персонального захисту інформаційних даних особи як-то здобувача освіти та наукових сервісів, учасника освітньо-наукового процесу, зацікавлених сторін системи менеджменту якості освіти та наукового дослідництва й інших ангажованих представників професійної зайнятості впродовж життя. У контексті глобальних соціальних, економічних, технологічних та демографрічних змін суспільство потребує системних і скоординованих змін у галузях культури, професійної зайнятості та розвитку технологічного забезпечення через цифрову трансформацію, які надають можливості створення новітніх та уможливлюють трансформацію традиційних освітніх моделей, модернізують діяльність 30 через зміни у стратегічних напрямах та освітньо-аксіологічних пропозиціях студентоцентрованого навчання. Запровадження цифрової трансформації освітньої галузі дає можливість керувати змінами, які сприяють еволюції освітніх моделей; інноваційний підхід до впровадження ефрективних методів навчання, можливостей розкриття академічного потенціалу через наслідування досвіду наукових досліджень, інтеграції освітньо-цифрових локальних та глобальних освітньо-наукових архітектур для квалітології управлінської взаємодії в 30 на засадах сталості. Використання освітніх технологій у забезпеченні реформування освітньої галузі розглядав науковий колектив на чолі Б. Меанс (1993) у аспектах ії інформатизації як превалюючої моделі викладання-навчання та ефективної передачі інформації студентам педагогами [1]. Вплив ІТК-технологій на розвиток малого та середнього бізнесу розглянуто в науковій монографії Е. Лефевр, Л. Лефевр (1996) у аспектах ІТ-забезпечення операцій 
роботи інформаційних систем інформатизації для бізнес управління, системного процесу прийняття стратегічних та виконавчих рішень, а також управління інформацією [2]. Як стратегічний інструмент покращення галузевої діяльності засобами інформаційних та телекомунікаційних технологій за призначенням розглядав Д. Бухаліс (1996) [3]. Розвиток галузей інформатизації та телекомунікації у контексті міжнародної безпеки розглянуто у роботі Першого комітету ООН (1998-2012рр.)., були рекомендовані національні стратегії, політики та передовий досвід у галузі безпеки інформаційнокомунікаційних технологій (далі - IKT) та визначено заходи нарощування їх потенціалу, представники урядів наголошували на праві кожної країни захищати свої інформаційні та телекомунікаційні системи, що розкрито у короткому звіті щодо процесу кіберполітики Е. Тікк-Рінгас [4]. Методологічні питання фрормування системи технічного забезпечення ITК-мереж у часописі «Системи та засоби» (2013) А. Зацарінний, Н. Буроменський та О. Гаранін описали основні поняття наукового тезаурусу; представили авторське бачення формування системи технічного забезпечення інформації та телекомунікаційних мереж як інтегрованої системної проблеми концептуального охоплення усіх сфрер суспільної життєдіяльності [5]. Дослідження чинників запоруки ефрективності роботи віртуальної команди в середовищі підтримки телекомунікацій презентовано у науково-метричному виданні «Телематика та інформатика» О. Саафеін, Г. Шаукхіан (2014), які актуалізували роль адміністраторів, менеджерів як керівників віртуальних команд галузі телекомунікацій для кропіткого вибору обґрунтованого режиму роботи при функціональному розподілі командної діяльності з надійними засобами інформаційно-технологічної (далі - IT) підтримки, як зазначено у посиланнях авторів у часописі «Журнал освіти інформаційних систем» 
[6]. У періодичному виданні прикладних та перспективних досліджень К. Разиисвари (2018) зазначає, що IКT забезпечують доступ до сучасних інформаційних даних на всіх рівнях як офріційному, так i неформальному засобами інформаційних мереж для підтримки та розвитку сфери освіти та науки [7]. Експериментальне дослідження щодо впровадження інформаційно-телекомунікаційних технологій у професійну підготовку вчителя розкрито Д. Берді, І. Усембаєвою (2015), було присвячено методичному забезпеченні освітнього процесу та технологіям навчання педагогів у освоєнні компетентностей інфрорматизації в предметній області викладання. Зактуалізовано відповідальність 30 у забезпеченні освітнього процесу з адекватним використанням ІТК-технологій [8]. Невирішеними аспектами у сфері підготовки майбутніх фрахівців засобами ITК-забезпечення 30 залишаються наріжні питання : узгодженої комплектації технологічних засобів; методологічного обґрунтування їх добору, функціональних параметрів та характеристик, операційності, масштабності та синхронізації з існуючим матеріально-технічним забезпеченням 30; профресійної компетентності як викладачів, які забезпечують підготовку майбутніх фрахівців, мережевих адміністраторів, модераторів, керівників 30, які організовують освітній процес за фрормами змішаного, мобільного, мережевого навчання.

Формулювання мети статті та завдань. Здійснення педагогічної розвідки щодо актуальності підготовки майбутніх фрахівців засобами інформаційно-телекомунікаційного забезпечення закладів освіти. Досягненню мети сприяє вирішення завдань: методичне обґрунтування питання дослідження; контент-аналіз інфрормаційнотелекомунікаційного забезпечення підготовки фахівців закладів освіти та конкретизація понятійно-категоріального апарату; систематизація інформаційно-телекомунікаційної ресурсної бази. 
Виклад основного матеріалу статті. Для розв'язання поставленої мети використовувалися методи: загальні теоретичні теоретико-методологічний аналіз наукової літератури з проблеми встановлення актуалізації підготовки майбутніх фахівців в 30 та застосування ІТК-забезпечення в освітньо-науковому процесі їх профресійної підготовки; систематизація засобів, інструментарію та ресурсів ІТК-забезпечення; спеціальні теоретичні методи аналізу аксіологічний та інституційний; системний, портфельний та причиннонаслідковий; проблемний. Та найбільш ефективним визначено методконтент аналізу для досліджень параметрів якісних характеристик i систематизації комунікативних характеристик джерельної бази, аксіології наповнення кількісних контентів (Б. Берельсон, П. Мэйрінг, К. Нойендорф, А. Кумар); практично-корисного досвіду застосування комп'ютерного підходу до змісту моделей аналізу (П. Дж. Стоун); методичних засад його застосування (К. Криппендорф), а також при формуванні бібліографії галузей наук та знань (М. Уайт, Е. Марш); методики діагностики наукових результатів, оцінювання текстових, аудіо-візуальних джерел (С. Стемлер); проблемно-контентного аналізу текстів при впровадженні та розгортанні комунікацій масової інформатизації (X. Іоффре, Л. Ярдлі); планування освітньо-наукового процесу через застосування віртуальних конференцій (Ф. Анрі); дослідження суб'єкт-об'єктних та суб'єкт-суб'єктних взаємин (Л. Бакстер); способів кодування аналізованих текстів (‥ Карлі) та візуалізованих образів (П. Белл) у соціальній взаємодії учасників системних процесів (Б. Прасад) $[10,11]$. Застосування методу контентаналізу $€$ найпоширенішим методичним забезпеченням прикладного вивчення теоретико-методичної джерельної бази, полягає у систематичному виділенні та ідентифікації одиниць змістовнометодологічних складових і літературних джерел, квантифікації 
отриманих інфрормаційних наукових даних та інтерпретації результатів задля оцінювання прогнозованих дій. Запити застосування полягають у низці методологічних вимог за допомогою яких обґрунтовано: узгоджену системну відповідальність виокремлених класифікаційних категорій у освітньо-політичних проблемах, ситуаціях, реаліях, які підлягали дослідженню; емерджентну системність застосування у розлогій амплітудній інформаційній базі доступних даних з елементами цифрової інформації, яка має цільовий компонент методології дослідження та може бути використана на практиці; надійну достовірність релевантності аналізу документального походження за встановленими правилами системної аналітики.

На концептуальному рівні вирізняють системи підтримки прийняття рішень, що керуються через: повідомлення від групи користувачів, які працюють над виконанням спільного завдання (з англ. - Communication-Driven, DSS); отримання даних (з англ. - Data Mining) та їх маніпуляції (з англ. - Data-Driven, DSS); пошук та маніпуляції неструктурованою інформацією, заданою у різних фрорматах документи (з англ. - Document-Driven, DSS); знання шляхом розв'язання проблемних завдань у вигляді фрактів, правил та процедур (з англ. - Knowledge-Driven, DSS); доступ і маніпуляції математичними, статистичними, фінансовими, оптимізаційними, імітаційними моделями (з англ. - Model-Driven, DSS) у інформаційних системах та сховищах зберігання (з англ. - Data warehouse) засобами IT (Інтернет та Інтранет) з інтерактивним аналітичним обробленням (з англ. - Online Analytical Processing, OLAP).

Організація управління у 30 здійснюється IT-засобами ITKплатформ інформаційного комплексу програмно-технічного обладнання, організаційних систем та нормативних баз, забезпечення інформаційних потоків в освітньому процесі; сукупність технічних та 
програмних засобів телекомунікаційної взаємодії та технологій організації адміністрування й використання розподілених інформаційних ресурсів. Інформаційно-телекомунікаційні інструменти - для створення інтерактивного контент-діалогу зі здобувачами освіmu: Kahoot! (https://kahoot.com/) - глобальна платформа, що сприяє створенню віртуального навчального середовища для створення ігор, вікторин, публікацій, презентацій для 30; Socrative (https://www.socrative.com/) - віртуальний онлайн-кабінет для діагностики навчальних досягнень здобувачів освіти; Wooclap (https://www.wooclap.com/) - веб-платфрорма 3 широкою функціональністю для створення інтерактивного контенту засобами мобільних пристроїв (смартфонів, планшетів); для створення вебсторінок: Google sites (https://sites.google.com/new) - складова функціоналу Google Диску, що надає змогу презентувати доступну інформацію за допомогою технології wiki; WIX (https://uk.wix.com/) конструктор повнофункціонального персоналізованого сайту.

Програмне забезпечення платформ управління навчанням: Moodle (https://moodle.org) - безкоштовне програмне забезпечення для викладачів, модераторів та здобувачів освіти (підтримується активною мережею сертифрікованих партнерів для сприяння у системі академічної освіти як портал для студентів, у асинхронному та синхронному навчанні (змішаному, мобільному та електронному), розроблення дистанційних курсів, гейміфрікації, відеоконфреренцій); Canvas (https://www.canvas.net/) - середовище системного управління навчанням для 30 з адаптацією до навчально-пізнавальної діяльності, з добором інструментів для навчання впродовж життя та професійний розвиток освітян об'єднує комплекс відкритих онлайн-курсів Canvas Network, які презентують досвідчені експерти та провідні установи; Talent (https://www.talentlms.com) - програмне забезпечення 
електронного навчання, що забезпечує підтримку та розроблення авторських курсів, відеоконференцій, гейміфікацію, масштабування профілів користувачів академічної освіти; Litmos (https://www.litmos.com) - мобільна онлайн-платформа з безпечним системним управлінням навчально-пізнавальної діяльності при освоєнні та розробленні навчальних курсів; Lessonly (https://www.lessonly.com) - програмне забезпечення управління індивідуальним та груповим навчанням в мережі Інтернет, сприяє розробленню та впровадженню практико-орієнтованих освітніх ресурсів для обміну практично-корисним досвідом освітньо-наукового процесу організації корпоративно-мобільного навчання; Easy (https://www.easyIms.com) - зрозуміла та зручна система управління навчанням для вироблення конкурентних організаційних рішень, особливостями якої є вікторини, іспити, курси та їх сертифікація; iSpring Learn (https://www.ispringsolutions.com) - хмаро-орієнтоване програмне забезпечення управління електронним навчанням 3 розширеною функціональністю у аспектах: створення облікового запису, розгортання, управління роботою користувачів та груп, брендування корпоративного навчального порталу та моніторинг результатів досягнень; Teachable (https://teachable.com) - онлайн-платформа для створення курсів та керування освітнім процесом, що не потребує знань 3 технічних налаштувань платформи; LearningStone (https://www.learningstone.com) - сучасне хмаро-орієнтоване програмне забезпечення управління електронним навчанням 3 блоковою побудовою системи; NEO (https://www.neolms.com/) - портативна система віртуальної організації, що призначена для використання педагогами з доступним дизайном автоматичного налаштування за типами застосованих пристроїв та обладнання з графічним каталогом, навігацією; Easygenerator (https://www.easygenerator.com/) 
програмний редактор електронних курсів, орієнтований на швидке створення та поширення навчального контенту; Gomo learning (https://www.gomolearning.com/) - хмарна платформа для створення електронних навчальних курсів (відеотренінги, відеокурси).

Комплекс інструментарію для роботи над створенням освітнього контенту з ІТК-забезпеченням професійної підготовки фрахівців, які систематизовані за видами: відео, аудіо, презентації, звукового контенту та симуляції. Інструментарій для створення електронних курсів: Articulate 360 (https://articulate.com/360/storyline) - комплексна система побудови, моніторингу та управління онлайн-навчанням (індивідуальні інтерактивні курси, обробка фото-, відео - шаблонов); Articulate Rise 360 (https://articulate.com/360/rise) - професійні продукти 3 функціональним набором компонентів - блоків 3 кастомізованим вмістом, діалогових тренажерів масштабованих сценаріїв; поширення і обмін курсами між модераторами програми, бібліотеки шаблонів різних форматів (текст, відео, аудіо, анімація, веб-об'єкти тощо); інструменти діагностики (тестові завдання відкритого та закритого типу), укомплектування додатків курсів, оприлюднення курсу у LMS-системі управління навчанням.

Інструменти для розроблення i обробки відео-контенту: Camtasia (https://camtasia.en.softonic.com) - створення відеоуроків й інструктажу для користувачів блогів і дистанційних курсів (мікронавчання, вебінари, тренінги); Vyond (https://www.vyond.com/) Інтернет-анімаційне програмне забезпечення для створення профресійних анімованих відео, навчальних мульторільмів 3 використанням персонажів або анімованої графріки; Powtoon (https://www.powtoon.com/) - візуальна онлайн-платформа комунікацій для створення відеоуроків, професійних відероликів з анімованими персонажами, візуальними, аудіо та відео шаблонами; Moovly 
(https://www.moovly.com/) - віртуальна платфрорма для створення та генерування мультимедійного контенту (анімовані відео та інформаційна графріка, відеопрезентації з графікою анімації); PlayPosit (https://go.playposit.com/) -освітня платформа для синхронізації контенту (інтерактивних відеоуроків, звітніть, діагностика, комунікація). Важливими інструментами для освітнього контенту в електронному курсі є сервіси для створення презентацій : Prezi (https://prezi.com) віртуальна платфрорма 3 широким фрункціоналом для створення презентацій за допомогою шаблонів інфографіки, тренінгів, електронних курсів; Powerpoint (https://office.live.com) - програма для створення презентацій, потужний інструмент зі традиційним інтерфейсом 3 профресійним дизайном і інтерактивними елементами прототипування; Google-презентації (https://www.google.com) віртуальний інструмент для створення онлайн-презентацій 3 корпоративним доступом; Keynote (https://www.apple.com/ru/keynote/) програма для портативного створення онлайн-презентацій з ефектами анімації та шаблонами; VoiceThread (https://voicethread.com/) - хмарний сервіс для створення і спільного обговорення медіаконтенту 3 можливістю голосового коментування та проведення відеоконференцій; для роботи зі звуковими файлами: Audacity (https://www.audacityteam.org/) - мультифункіональний аудіоредактор та рекордер з можливістю редагування, оцифрування та зміни параметрів звукових фрайлів, їх запису, накладення треків з ефектами.

Інформаційно-методичні ресурси науково-технічної діяльності та дослідництва у напрямах мережевої організації освітнього процесу для реалізації академічного потенціалу 30 та удосконалення методології наукового пізнання; програмні продукти- Trello (https://trello.com/uk) - полімодусна система управління проектною діяльністю з використанням Канбан-метода; Asana (https://asana.com) - 
оперативна пошукова система синхронізованого управління колективними проектами 3 формуванням планів i координації їх виконання; Pyrus (https://pyrus.com/ru) - система для організації процесу підготовки фрахівців з ITК-забезпеченням; Microsoft Teams (https://www.microsoft.com/uk-ua/microsoft-365/microsoft-teams/free) віртуальний безкоштовний доступний центр командної діяльності в Office 365 від Microsoft, який синхронізує користувачів, інформаційний контент і комунікаційні засоби, необхідні для синергетики колективної роботи, спільний простір у хмарному сховищі (файлообмінник), чати для онлайн-нарад та корпоративні програми; Granatum Solutions (https://granatum.solutions/) - поліфункціональна платформа для ефективної онлайн-взаємодії та розвитку ІТ-бізнесу, вирішення проектних бізнес-завдань комерціоналізації освітніх і наукових проектних видів онлайн і офлайн робіт; «ТренінгСпейс» (https://www.trainingspace.online/) - Digital-платформа для корпоративних навчальних центрів, тренінгових, просвітницьких, дозвіллєвих, рекреаційних, реабілітаційних дорадчо-консалтингового обслуговування за допомогою сучасних цифрових сервісів та інформаційної аналітики.

Корпоративна робота в освітньому процесі, прототипування, створення документів, презентацій, таблиць визначає вибір інструментів: Notion (https://www.notion.so/) - єдиний простір для нотатків, завдань, вікі-сторінок та баз даних; Google: G Suite for Education (edu.google.com/products/gsuite-for-education) - гнучкі інструменти для організації супроводу освітнього процесу (документи, таблиці, презентації) зі збереженням інформації на Гугл-диску (з англ. Google Drive) та доступу у режимі офрлайн; Confluence (https://www.confluence.com/) - веб-корпоративний динамічний простір для ефективної командної роботи над творчими проектами, 
інноваціними ідеями; Miro (https://miro.com) - онлайн-платфрорма візуального співробітництва, середовище веб-візуалізації та дизайнпланування творчих проектів; Draw.io (https://drawar.io/) - програмне забезпечення для створення блок-схем та онлайн-діаграм. Інструменти для відпрацювання навичок програмування та умінь проектування програм для корпоративної діяльності: Colaboratory (https://colab.research.google.com) - додаток сервісу Google, що надає доступ до грасрічних процесорів, документів корпоративного використання; сприяє аналізу та візуалізації даних можливостей провідних бібліотек Python; автоматизованому навчанню, Kaggle (https://www.kaggle.com/) - середовище для організації розвитку наукових даних 3 графрічними процесорами, об'ємним сховищем зберігання наукових даних з пошуковою сисемою і можливістю ведення діалогу. Інструменти для створення візуально-графрічного контенту: Piktochart (https://piktochart.com/) - веб-інфографічний додаток для створення візуальних зображення за допомогою тематичних шаблонів (діаграми, графріки, схеми, таблиці, постери); Infogram (https://infogram.com/) - онлайн-інструмент візуалізації інфографріки, діаграм і інтерактивних схем; Adobe Photoshop (https://www.adobe.com/ua/) - графрічний редактор 3 поліваріантним функціоналом креативної обробки зображень.

Висновки. Застосування методу контент-аналізу забезпечило імітаційне уявлення щодо об'єкту дослідження у ході безпосереднього спостереження; використано як методика інтенсивного аналізу змістовно-методологічної частини конкретно заявленої ITK ресурсної бази; зреалізовано для пошуку оперативної інфрормації наукового тезаурусу, текстових документів, в тому числі радіо, телетрансляційного зв'язку; включає стандартизовані освітньоуправлінські процедури ідентифрікації категорій відхилень в інтересах 
дослідження щодо частоти кількісно-якісних варіантів параметрального оцінювання категорій змістовних складових, які можуть бути використані в елементарних компонентах ІТК комп'ютерних програм. Здійснено методичне обґрунтування актуалізації підготовки майбутніх фрахівців засобами ITК-забезпечення 3О. Конкретизовано напрями наукових шкіл фундаторів контент-аналізу ІТК-забезпечення 30. Систематизовано ITK-ресурсну базу: системи підтримки прийняття рішень; ІТК-інструменти для створення інтерактивного контент-діалогу зі здобувачами освіти та для створення веб-сторінок; платформи управління навчанням; інструментарій для створення електронних курсів та для розроблення і обробки відео-контенту; сервіси для створення презентацій та роботи зі звуковими файлами; інформаційнометодичні ресурси науково-технічної діяльності та дослідництва (програмні продукти); Інструменти корпоративної роботи в освітньому процесі; відпрацювання навичок програмування; створення візуальнографрічного контенту.

\section{תimepamypa:}

1. Using technology to support education reform paperback (1993) by B. Means (editor), J. Blando (editor), K. Olson (editor), T. Middleton (editor). University of Michigan Library. $124 \mathrm{p}$.

2. Lefebvre E., Lefebvre L. A. (1996) Information and telecommunication technologies: the impact of their adoption on small and medium-sized enterprises. International development research centre. 132 p.

3. Buhalis D. (1996) Information and telecommunication technologies as a strategic tool for tourism enhancement at destination regions. Information and Communication Technologies in Tourism, pp. 131-142. 
4. Tikk-Ringas E. (2012) Developments in the Field of Information and Telecommunication in the Context of International Security: Work of the UN First Committee 1998-2012. 14 p.

5. Zatsarinnyy A. A., Buromenskii N. G., Garanin A. I. (2013) Methodological questions of formation of the system technical support of information-telecommunication networks. Sistemy $i$ Sredstva Informatics, Volume 23, Issue 2, 2 C. 154-169 DOI: https://doi.org/10.14357/08696527130211 (2020, вересень 20).

6. Saafein O., Shaykhian G. A. (2014) Factors affecting virtual team performance in telecommunication support environment. Telematics and Informatics, № 31, pp. 459-462.

7. Ratheeswari K. (2018) Information Communication Technology in Education. Journal of Applied and Advanced Research, Vol 3, Suppl. 1, S. 45-47. DOI: http://dx.doi.org/10.21839/jaar.2018.v3iS1.169 (2020, вересень 20).

8. Berdi D., Usembayeva I., Ramankulov S., Saparbekova G., Berkinbaev M. (2015) Results of the Experimental Research on the Introduction of Information and Telecommunication Technologies in Teacher's Professional Training. Indian Journal of Science and Technology. Vol. 8, Issue 27, pp. 1-11. DOI: 10.17485/ijst/2015/v8i27/82620 (2020, вересень 20).

9. Deumes R. (2008) Corporate risk reporting: a content analysis of narrative risk disclosures in prospectuses. Journal of business communication, Vol. 45, № 2, pp. 120-157. DOI: 10.1177/0021943607313992 (2020, вересень 20).

10. Кашина Г. С. Науково-природнича підготовка педагогів у системі післядипломної освіти засобами інфрормаційно-технологічного забезпечення: монографрія. Херсон : Вид-во «ОЛДІ-ПЛюС», 2018. 315 с. 
11. Енциклопедія державного управління: у 8 т. / за ред. Ю. В. Ковбасюк. Київ: НАДУ, 2011. Т. 2: Методологія державного управління / за ред. Ю. П. Сурмін, П. І. Надолішній, 2011. 692 с.

\section{References:}

1. Using technology to support education reform paperback (1993) by B. Means (editor), J. Blando (editor), K. Olson (editor), T. Middleton (editor). University of Michigan Library. 124 p. [in English].

2. Lefebvre E., Lefebvre L.A. (1996) Information and telecommunication technologies: the impact of their adoption on small and medium-sized enterprises. International development research centre. 132 p. [in English].

3. Buhalis D. (1996) Information and telecommunication technologies as a strategic tool for tourism enhancement at destination regions. Information and Communication Technologies in Tourism, pp. 131-142. [in English].

4. Tikk-Ringas E. (2012) Developments in the Field of Information and Telecommunication in the Context of International Security: Work of the UN First Committee 1998-2012. 14 p. [in English].

5. Zatsarinnyy A. A., Buromenskii N. G., Garanin A. I. (2013) Methodological questions of formation of the system technical support of information-telecommunication networks. Sistemy i Sredstva Informatics, Volume 23, Issue 2, C. 154-169 Retrieved from DOI: https://doi.org/10.14357/08696527130211 [in English].

6. Saafein O., Shaykhian G.A. (2014) Factors affecting virtual team performance in telecommunication support environment. Telematics and Informatics, № 31, pp. 459-462. [in English].

7. Ratheeswari K. (2018) Information Communication Technology in Education. Journal of Applied and Advanced Research, Vol 3, Suppl. 1, S. 45-47. Retrieved from DOI: http://dx.doi.org/10.21839/jaar.2018.v3iS1.169 [in English]. 
8. Berdi D., Usembayeva I., Ramankulov S., Saparbekova G., Berkinbaev M. (2015) Results of the Experimental Research on the Introduction of Information and Telecommunication Technologies in Teacher's Professional Training. Indian Journal of Science and Technology. Vol. 8, Issue 27, pp.1-11. $\quad$ Retrieved from DOI: 10.17485/ijst/2015/v8i27/82620 [in English].

9. Deumes R. (2008) Corporate risk reporting: a content analysis of narrative risk disclosures in prospectuses. Journal of business communication, Vol. 45, № 2, pp. 120-157. Retrieved from DOI: 10.1177/0021943607313992 [in English].

10. Kashyna G. S. Naukovo-pryrodnycha pidgotovka pedagogiv u systemi pislyadyplomnoyi osvity zasobamy informacijno-texnologichnogo zabezpechennya [Scientific and natural training of teachers in the system of postgraduate education by means of information and technological support]: monografiya. Xerson: Vyd-vo «OLDI-PLYuS» [OLDI-PLYuS], 2018. 315 s. [in Ukrainian].

11. Encyklopediya derzhavnogo upravlinnya [Encyclopedia Of Public Administration]: u 8 t. / za red. Yu. V. Kovbasyuk. Kyyiv: NADU [National academy for public administration under the president of Ukraine], 2011. T. 2: Metodologiya derzhavnogo upravlinnya [Methodology of Public Administration] / za red. Yu. P. Surmin, P. I. Nadolishnij, 2011. 692 s. [in Ukrainian].

Citation: V. Tymoshenko (2020). ACTUALIZATION OF TRAINING OF FUTURE SPECIALISTS BY MEANS OF INFORMATION AND TELECOMMUNICATION SUPPORT IN EDUCATIONAL INSTITUTIONS. Frankfurt. TK Meganom LLC. Paradigm of knowlege. 5(43). doi: 10.26886/25207474.5(43)2020.9

Copyright: V. Tymoshenko (․ 2020. This is an openaccess article distributed under the terms of the Creative Commons Attribution License (CC BY). The use, distribution or reproduction in other forums is permitted, provided the original author(s) or licensor are credited and that the original publication in this journal is cited, in accordance with accepted academic practice. No use, distribution or reproduction is permitted which does not comply with these terms. 